Artigos 


\title{
O MODELO LITERÁRIO HUMANISTA E A LEGITIMAÇÃO DO PINTOR ARTISTA NA FRANÇA DO SÉCULO XVII
}

Celina Maria Moreira de Mello*

\begin{abstract}
RESUMO: A França do século XVII confere à Literatura um estauto superior ao da Pintura. Apresentamos o momento fundador de novas relaçōes de sentido que se tecem entre a Literatura e a Pintura, em um recorte que denominamos de espaço-histórico clássico, no qual a tradiçāo literária humanista vem servir de modelo para o processo de valorização do pictórico. O espaço-histórico aqui enfocado é o da fundação da Real Academia de Pintura e Escultura, que se estrutura visando conferir a seus membros um estatuto intelectual e social análogo ao dos escritores que haviam sido anteriormente congregados pela Academia Francesa de Letras. $O$ pintor aproxima-se do poeta e verá, no letrado humanista, o modelo a seguir para compor a nova personagem social do artista.
\end{abstract}

PALAVRAS-CHAVE: Literatura francesa; pintura; gênero.

\section{Introdução}

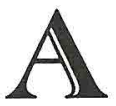

França do século XVII, na esteira de uma tradição medieval, que não se modificara, fundamentalmente, malgrado o movimento renascentista, confere à Literatura um es-

* Universidade Federal do Rio de Janeiro - UFRJ. 
Melio, Celina Maria Moreira de. O modelo literário humanista e a legitimação do pintor...

tatuto superior ao da Pintura. Do século XVII ao século XIX, em um contínuo processo de transformação dos valores sócio-estéticos que lhes são atribuídos, vemos progressivamente a Literatura e Pintura integrarem o campo da Arte, que por sua vez contribuem para constituir. Apresentamos, a seguir, algumas reflexões sobre um dos momentos fundadores das novas relações de sentido e valor, que se tecem entre a Literatura e a Pintura, na cultura francesa, em um recorte que denominamos de espaço-histórico clássico. Trata-se de um espaço discursivo construído pelo movimento de investigação das relações que se tecem entre dois campos que vão ser constituídos compartilhando funções sociais, espaço que resulta da recusa de abordagens de cunho temporal, lineares e marcadas pela idéia de progresso. No espaço-histórico clássico, de modo inequivoco, a tradição literária humanista vem servir de modelo para o processo de valorização do pictórico, na constituição de uma teoria da pintura e nos valores atribuidos aos gêneros acadêmicos.

O espaço-histórico clássico francês tem como um de seus marcos iniciais a fundação da Real Academia de Pintura e Escultura, que se estrutura visando conferir a seus membros um estatuto intelectual e social análogo ao dos escritores que haviam sido congregados pela Academia Francesa de Letras, fundada anteriormente. O modelo letrado reconfigura-se no campo da pintura e da escultura, em seus estatutos, atividades e hierarquias. A concepção estética dita acadêmica e uma rígida hierarquia de gêneros contribuem para esse processo de valorização. Evidenciam-se, neste processo, os mecanismos de legitimação e consolidação de prestígio do campo literário.

\section{O Santeiro e o pintor}

A fundação da Real Academia de Pintura e Escultura, solicitada em 1648, quando Luís XIV tinha dez anos, associa-se às figu- 
ras do Rei e de seus poderosos ministros, Richelieu primeiro e depois Mazarino. Vincula-se, portanto, ao processo de fortalecimento do poder centralizador e absoluto do rei de França, Luís XIV, que se iniciara no reinado de Luís XIII, de acordo com as diretrizes políticas traçadas por Richelieu e que continuaram a ser seguidas por Mazarino. A Real Academia de Pintura e Escultura tinha o propósito explícito de diferenciar seus membros dos pintores e escultores artesãos, submetidos ao estrito controle das Corporações de Ofício medievais, uma vez que a Corporação dos pintores e escultores, que se organizara em Paris em 139i, conseguira, e ainda mantinha, o privilégio - verdadeiro monopólio - da prática das artes (cf. Becq, 1994: 191 e Heinich, 1993).

A luta de um grupo de pintores e escultores por um novo espaço profissional e institucional inscreve-se em uma tensão maior no campo político francês dilacerado, à mesma época, pela Fronde, guerra civil, em que a nobreza parlamentar (noblesse de robe) e a nobreza feudal (noblesse d'épée) unem-se contra um poder real centralizador e cada vez mais opressivo. Por um lado, os Acadêmicos solicitam e obtêm a proteção de um rei absoluto, cujo poder ainda contestado necessita de alianças e fortalecimento. Por outro lado, os Mestres da Corporação são apoiados pelo Parlamento, ou seja, por setores influentes de uma burguesia de magistrados. De 1648 a 1655, entre a solicitação que a funda e o efetivo registro da Academia, os choques entre Acadêmicos e Mestres serão marcados por essa inscrição em um conflito de caráter eminentemente social e politico.

Como a Real Academia de Pintura e Escultura tinha o objetivo específico de estabelecer uma diferença entre seus membros e os artesãos regidos por uma organização corporativa, ela organizase de modo a acentuar o seu caráter elitista e "intelectual" e, para legitimar-se, recorre à proteção do rei e a valores humanistas, aos quais, por sua vez, ela vem conferir legitimidade. Assim, em uma verdadeira manobra de valorização do estatuto social de seus mem- 
Mello, Celina Maria Moreira de. O modelo literário humanista e a legitimação do pintor...

bros, a Academia atuará como uma instância institucional de transformação dos valores atribuídos às práticas de seus pintores e escultores, apresentado-as como práticas não mais artesanais, ou seja, mecânicas ou manuais, mas artísticas, vale dizer, liberaỉs. ${ }^{1}$ Segue, nesse movimento, o modelo de suas congêneres e predecessoras, as Academias de Pintura já existentes na Itália, desde o Renascimento, embora sua inscrição social e politica apresente, na França, características que lhe são próprias.

A solicitação é feita, em 1648, em uma carta dirigida ao rei e ao Conselho de Ministros, por Martin de Charmois. Este, significativamente, era membro de uma pequena nobreza de provincia e toma a palavra, já em nome da Academia. O discurso de Charmois inspira-se em inúmeros textos produzidos na Itália, a respeito das artes, assim como do Projet de l'Académie pour servir de préface à ses statuts (1635), de autoria de Nicolas Faret, para a Academia Francesa de Letras (cf. Heinich, 1993: 12-3 e nota 16). Deste modo, a Real Academia de Pintura e Escultura visa conferir a seus membros um estatuto intelectual e social semelhante ao de seus congêneres da Itália, mas mais do que isso, análogo ao dos escritores que haviam sido congregados pela Academia Francesa de Letras, fundada anteriormente por Richelieu em 1634 e que desempenhou um importante papel no fortalecimento da monarquia absoluta e na constituição do campo literário neoclássico.

A carta de Charmois integra os discursos constituintes do campo pictórico (cf. Mainguenau \& Cossutta, 1995: 112-25), a um só tempo solicita a fundação da Academia e constitui seu ato fundador, desenvolvendo uma série de argumentos que vêm legitimar

1 'Se o termo 'mecânico' referia-se em seu sentido próprio àquilo que exige o uso da mão, significava, igualmente, em um sentido figurado, com uma conotação moral, 'avaro' ou 'mesquinho', o espaço semântico do termo é comparável a nosso atual 'pobre'; em contrapartida, o termo 'liberal', em sentido figurado, significava, como ainda hoje significa, 'generoso'. Deste modo, essa distinção não apenas servia para situar, mas para uma classificação hierárquica e um julgamento ético e até mesmo estético". Неinich, 1993: 8. Trad. do autor. 
a existência deste grupo de pintores e escultores e lhes conferir um novo estatuto social. Trata-se de diferenciar, por seus conhecimentos, por seu domínio técnico e, sobretudo, pela inscrição em uma tradição da Antigüidade clássica, e não mais medieval, o grupo dos Acadêmicos do grupo dos Mestres.

Ao rei e a nossos senhores de seu Conselho - Majestade, a Academia dos Pintores e Escultores cansada das perseguições que sofre há longos anos pelo desagrado de certos Mestres Juramentados, que só assumem o nome de pintores e escultores para oprimir aqueles que consumiram sua Juventude no trabalho e no estudo das belas coisas a fim de merecer este título, encontra-se afinal.obrigada a se prosternar aos pés de Vossa Majestade, para suplicar-lhe mui humildemente e lhe Expor que a paciência com a qual suportaram essas Violências inflou a tal ponto a coragem de suas partes que eles pretendem não apenas sujeitar os mais sábios nessa arte a trabalharem para aqueles que misturam suas cores e que dão polimento a suas estátuas, porque eles compraram a qualidade de Mestres, mas ainda limitar o poder de Vossa Majestade, reduzindo a um certo número aqueles que ela honrou com o nome de seus pintores e escultores, por um efeito da ignorância, que não podendo suportar o brilho da virtude, a quer envolver em suas trevas, para impedir que se possam discernir seus defeitos em relação à beleza da ciência. $^{2}$

A arte, aqui entendida como conhecimento técnico, do fazer da imagem como mestria controlada por uma corporação, correspondia, no sistema de valores medievais, a uma atividade manual, e é representada, na carta, depreciativamente. Importava, para os acadêmicos, legitimar-se como detentores "da beleza da ciência" e diferenciar bem os dois grupos, pois a prática de uma atividade manual, dita mecânica, desonraria tanto os burgueses quanto os nobres que a ela se dedicassem. A furidação da Academia assinala,

2 Requête de M. de Charmois, apud Heinich, 1993: 232. Trad. do autor. 
Mello, Celina Maria Moreira de. O modelo literário humanista e a legitimação do pintor...

portanto, uma importante modificação dos grupos sociais de pintores e escultores que almejam distinguir-se de santeiros (imagiers) e marmoreiros (marbriers).

Neste verdadeiro processo de construção de uma nova identidade e da constituição de um novo grupo de atores sociais, Charmois, logo no início de sua solicitação, ataca, com violento desprezo, a corporação de Mestres pintores e escultores. Ele opõe o grupo de Pintores e Escultores do rei - título obtido por mérito - que se caracteriza pelo estudo, saber, virtude e ciência, ao de Mestres ignorantes e prepotentes, que se prevalecem de privilégios inerentes a um título comprado. Habilmente, faz ver ao rei que pretender "sujeitar os mais sábios nessa arte a trabalharem para aqueles que misturam suas cores [santeiros] e que dão polimento a suas estátuas [marmoreiros]" equivale a pretender "limitar o poder" do rei. Por outro lado, pintor e escultor, marcados pela chancela da Academia, vincular-se-iam, doravante, não mais às artes mecânicas mas às artes liberais. A venda de quadros ou contratação de serviços de pintores da Academia será prevista em seus estatutos, de modo a que não se confundam, quanto a este ponto, com o comércio dos santeiros. A necessidade de construir e fortalecer um espaço institucional que sirva de fiador de uma identidade de artista corresponde ao ambíguo lugar social do pintor humanista que, letrado, desvincula-se da classe dos artesãos, sem com isso vincular-se à elite aristocrática ou à burguesia enriquecida.

\section{Ut pictura poesis}

A carta de Charmois desenvolve uma linha argumentativa que à primeira vista pouco se fundamenta em questões que, hoje, chamariamos de estéticas. Podemos observar dois grandes grupos de argumentos. $O$ primeiro prende-se à importância das atividades responsáveis pela construção e a divulgação da imagem do rei. Pin- 
tores e escultores aparecem, claramente, como seus principais propagandistas. Ora, se na formulação que Richelieu consagrara para legitimar um monarca absoluto, o rei é o lugar-tenente, o representante de Deus na Terra, glorificar e difundir a imagem do rei significa igualmente glorificar e difundir a imagem de Deus. E somente os Acadêmicos detêm o conhecimento necessário para a perfeita consecução de retratos e estátuas em que o rei é representado. A conclusão lógica é a de que Luís XIV deverá retirar da Corporação o controle destas atividades, que são vitais para o fortalecimento do poder real:

A Academia [...] ousará dizer que embora Vossa Majestade se dê a conhecer por ações bastante notáveis, seus retratos que são levados por todas as partes do mundo não deixaram de contribuir Infinitamente para acrescentar a adoração dos estrangeiros à admiração que a Fama havia feito nascer em seus espíritos. ${ }^{3}$

O segundo grupo de argumentos caracteriza-se por recorrer a uma tradição erudita, cujo referente inequivoco é o humanismo renascentista. Um rei que tem apenas dez anos, mas que Charmois compara a Alexandre Magno, não poderá deixar de devolver aos artistas sua "primeira liberdade", aquela de que, afirma a carta, usufruiam na Antigüidade:

[...] eles [os acadêmicos] recorrem ao poder soberano para serem recolocados em seu lustre, assim como estavam no tempo de Alexandre em A academia de Atenas, onde todos sabem que eles ocupavam o primeiro lugar entre as outras artes liberais: e como Vossa Majestade começou desde sua infância a produzir ações mais maravilhosas que este Príncipe fez no vigor de sua juventude, eles têm o direito de esperar serem libertos dessa opressão, uma vez que é uma obra digna de Vossa Majestade, e farão glória de suas perseguições

Requête de M. de Charmois, apud Heinich, Nathalie, 1993: 234. 
MELlo, Celina Maria Moreira de. O modelo literário humanista e a legitimação do pintor...

passadas devendo sua liberdade à mão de um príncipe, cujo nascimento e cujas perfeições em uma idade tão tenra provocam a admiração de todo o universo. ${ }^{4}$

A carta lança mão de argumentos fundamentados na tradição humanista, como a necessidade de se voltar a uma idade de ouro que se situaria na Antigüidade clássica e em que pintores e escultores teriam gozado de prestígio e reconhecimento. Recorre, então, a um conjunto de episódios - cita Apeles, lendário pintor dos retratos de Alexandre Magno - que integram um imaginário da superioridade da pintura em relação às outras formas de expressão artística. Pintores e escultores solicitam, pois, viverem, um "Renascimento" de seu prestígio perdido em uma carta que atribui a esse novo grupo social uma origem elevada, que lhes conferiria o direito de recuperar uma antiga posição social superior. A fundação da Academia apresenta-se, portanto, como um ato de reparação histórica, que permitiria a um grupo recuperar uma suposta situação anterior de superioridade, processo que se desenrola em uma espécie de ficção histórica. Mas acima de tudo, o texto mesmo da solicitação é uma prova eloqüente de que aquela Academia detém os conhecimentos necessários de Mitologia e História, que capacitam os acadêmicos para sua missão política de fortalecimento do poder, tanto do trono quanto da Igreja. E deixa implícito que os vis $\operatorname{artesãos~}^{5}$ que têm a pretensão de os controlar, por meio da Corporação, tudo ignoram desse mundo erudito. Entretanto, no que se refere à lendária superioridade dos pintores, Charmois, prudente, evita um confronto com o campo letrado:

A Academia, contudo, não deseja fazer deduções deste louvor, a fim de marcar sua superioridade sobre os oradores ou sobre os escritores, uma vez que sua meta e a dos pintores

4 Requête de M. de Charmois, apud Heinich, Nathalie, 1993: 233.

5 Por duas vezes chamados de "abjetos" por Charmois. 
não é diferente, que cada uma dessas artes possui suas belezas, que um faz com o pincel aquilo que o outro faz com a pena, e que, em uma só palavra, seu desígnio consiste apenas em expressar as coisas tal como as vemos, ou como as havemos concebido. ${ }^{6}$

E embora Charmois, no final da carta, retorne ao tema da superioridade da pintura em relação a todas as formas de expressão artística, a estratégia argumentativa que adota, denegando a superioridade dos pintores sobre os escritores, lhe permite apresentar de modo mais aceitável seu objetivo que é o de os colocar em niveis comparáveis, quanto a suas metas e seus meios. Ao evocar a concepção chamada de Ut pictura poesis, ${ }^{7}$ confere a pintores e escritores a mesma identidade de artistas, por terem ambos o mesmo designio, aquilo que, em seu fazer, expressa a Idéia.

Categoriza-se essa carta como um discurso constituinte, porque, de certo modo, a Academia funda-se pelo ato mesmo de solicitar ao rei sua proteção: "A pretensão associada ao estatuto de discurso constituinte é o de fundar e de não ser fundado". (Maingueneau \& Cossutta, 1995: 112). Ao colocar-se sob a proteção do rei, vincula seu ato de fundação à função paterna, geradora, de que o monarca absoluto é um representante emblemático. ${ }^{8} \mathrm{~A}$ carta de Charmois produz, simbolica e. discursivamente, um grupo que se inscreve em uma tradição letrada, que por sua vez contribui para fortalecer. O grupo de Acadêmicos diferencia-se do grupo de Mestres, não apenas quanto à liberdade de seu exercício profissional, mas como um novo grupo social que se legitima pelo processo mesmo de sua emergência. E também abre-se a possibi-

6 Requête de M. de Charmois, apud Heinich, Nathalie, 1993: 235.

7 A doutrina renascentista e clássica do Ut pictura poesis, no paralelo entre artes da imagem e artes da linguagem, fazia do literário o referente do pictórico, o que na verdade inverte o sentido do verso de Horácio - "Ut pictura poesis erit": o poema é como um quadro. cf. Lee, Rensselaer W. 1998 (1967): 7-8.

8 A carta designa um Outro (Lacan), Deus, fonte e origem de valor, Pai que gera uma comunidade que nasce "à sombra do poder". 
Mello, Celina Maria Moreira de. O modelo literário humanista e a legitimação do pintor...

lidade, para este grupo, de produzir e aglutinar discursos que reforçam sua identidade e fortalecem suas posições junto ao poder real. E, finalmente, conforme foi assinalado, a fundação desse grupo apoia-se na existência de um grupo de escritores congregados em uma Academia, que lhe serve de modelo institucional e que contribuem para legitimar em sua posição no campo das Belasletras.

A brilhante exibição de conhecimentos eruditos realizada por Charmois vem demonstrar que os novos acadêmicos são tão merecedores da proteção do rei quanto os poetas. O pintor (e o escultor) aproxima-se, deste modo, do poeta e verá, no Letrado, o modelo a seguir para compor uma nova personagem social, afastando-se da personagem do artesão.

\section{Belas-letras e Belas-artes}

A Real Academia de Pintura e Escultura, em seus primórdios, é fundada e formada por uma elite, um grupo de pintores e escultores, em que a maioria já detém o título seja de pintor de história, seja de pintor ou escultor do rei, artifício e privilégio que, àquela época, lhes permitia fugir à jurisdição corporativa. Deste grupo de fundadores, o único que é também membro da Mestria é Charles Le Brun, pintor de história e primeiro pintor do rei (cf. Heinich, 1993: 240). A concepção de arte que defendem, privilégio de uma elite, corresponde a uma visão de mundo humanista, com seus referentes eruditos e suas implicações sociais, pois como observa Hautecoeur:

A arte que, até o Renascimento, como bom acólito da Igreja, dirigia-se a todos os fiéis, tanto os mais humildes como os mais letrados, liberta-se e torna-se, na concepção dos doutores leigos, o privilégio de uma elite. A idéia de um deleite reservado de um gozo aristocrático, integra a concepção do 
humanismo. Humanismo não significa "que se dirige a toda a humanidade", mas "que modela o homem perfeito". ${ }^{9}$

A fundação da Academia corresponde, pois, a uma certa "intelectualização" e "elitização" da arte, inerente ao Humanismo, em tensão com o aspecto coletivo e popular da fruição das obras de arte, na Idade Média. Mas envolve, também, questões diretamente vinculadas ao exercício "profissional" desta atividade, social e economicamente apresentada como análoga ao das Letras. Annie Becq (1993: 191) assinala que a constituição do sintagma "belas-artes", de certo modo, marca o reconhecimento de uma mudança de estatuto do artista.

Belas-artes (beaux-arts) será uma expressão registrada em 1752, um século depois da fundação da Academia, formada a partir de seu modelo, o sintagma Belas-letras (belles lettres). Ora, as Belas-letras, expressão já em uso no século XVI, referem-se à eloqüência, à gramática e à poesia, reconhecidas como artes liberais no sistema medieval de organização dos conhecimentos. ${ }^{10} \mathrm{O}$ sintagma belas-artes vem confirmar que o campo da pintura acadêmica é o de uma arte liberal. Belas-artes serão, então, ditas aquelas voltadas para o belo nas artes plásticas, ou seja nas artes das formas: arquitetura, gravura, pintura e escultura. A formação mesma do sintagma manifestará o êxito da instituição acadêmica. Seria demasiado simples, contudo, pensar que a Academia suprime o pintor artesão ou faz, automaticamente, da pintura um campo análogo ao das letras. O santeiro artesão e·o pintor criador correspondem a dois sistemas que coexistirão ainda por muito tempo na sociedade francesa. ${ }^{11}$

9 Hautecoeur, 1963: 9.

10 Na Idade Média, o conhecimento organiza-se no trivium: gramática, dialética e retórica e no quadrivium: aritmética, geometria, astronomia e música.

1 cf. Anexos 32, 33: La "Table démonstrative de l'Académie des Sciences" selon Bullart (1682) e Le "Système figuré des connaissances humaines" selon l'Encyclopédie (1751) In: HeINICH, Nathalie, 1993: 280-2. 
Mello, Celina Maria Moreira de. O modelo literário humanista e a legitimação do pintor...

As atividades dos acadêmicos, definidas pelos estatutos, limitam-se, em uma primeira fase, a debates e conferências sobre temas téoricos, voltados para a elaboração de um conjunto de doutrinas, sobre o qual os acadêmicos fundamentarão sua autoridade. Mais tarde, serão previstas atividades de ensino, em que são sistematizadas e impostas as regras estabelecidas por esse corpo teórico e que asseguram a permanência da Academia como instituição. Os debates e conferências são atividades liberais, as quais vêm comprovar os níveis de erudição e as capacidades de reflexão e elaboração discursiva exigidas dos acadêmicos e que os legitimam como pertencendo ao seleto grupo de humanistas. A este respeito Gombrich comenta que "[...] os antigos métodos, pelos quais os grandes mestres do passado tinham aprendido seu ofício, triturando cores e ajudando os mais velhos, entraram em declínio" (Gombrich, 1993: 379).

Um dos temas que serão regularmente tratados pelos acadêmicos, em debates e conferências, é o da comparação entre as artes, exercício retórico secular. Era citada, freqüentemente, a fórmula atribuída por Plutarco a Simônides de Ceos: “a pintura é uma poesia muda,/a poesia uma pintura que fala" (apud Lee, 1998: 7). Entretanto, na falta de um tratado teórico sobre a pintura que fosse mais do que um manual de técnicas e prescrições, a Academia contribui para elaborar uma teoria da pintura que, em muitos pontos, evoca uma teoria da literatura.

Essa construção teórica toma de empréstimo e os articula em um corpo de doutrina e ensino, passagens em que os grandes autores da tradição poética humanista se referem à poiesis e até mesmo, algumas vẹzes, especificamente à pintura. São referências constantes, entre outros textos, a Poética de Aristóteles, quando este trata dos diferentes tipos de poesia segundo os objetos imitados (Poética II, 48 ) e a Arte poética de Horácio, em especial, a Introdução dn primeiro capítulo que concede a pintores e poetas serem livres em sua imaginação (v. 1-13) e os versos já citados (v. 361-5), 
presença obrigatória em todo discurso que compare a poesia e a pintura.

Os textos de Aristóteles e Horácio apresentam, certamente, uma analogia entre poesia e pintura, mas hả que se observar que são citações cortadas de seu contexto original e que constituem mais um argumento de autoridade do que propriamente uma teoria poética da pintura. Na verdade, realizando uma releitura das poéticas clássicas, o Renascimento havia elaborado um corpo teórico que tenta dar conta de múltiplas questões voltadas para a representação, em seus desdobramentos quanto a temas e gêneros, afastando-as progressivamente do tratamento teólogico que estas haviam assumido na Idade Média cristã. Merecem destaque uma poética da imitação, a importância conferida à invenção em detrimento da execução, de acordo com a tradição da retórica, e uma hierarquia dos gêneros pictóricos que se fundamenta, sobretudo, na Poética de Aristóteles.

A teoria da imitação (imitatio) resulta de um debate que já se colocara na Antigüidade clássica e que atravessara os séculos como uma interrogação enlaçada a inquietações filosóficas: nas fronteiras do visivel, o que o pintor oferece ao nosso olhar? Para responder, a teoria da imitação oscilará entre dois caminhos, revendo as formulações prescritivas de Aristóteles e de Platão quanto àquilo que o artista deve imitar. A teoria aristotélica é a da imitação seletiva da natureza tal como ela deveria ser e não tal como ela é, concepção defendida sobretudo por Dolce, e que resulta em um preceito da imitação, não mais da natureza mas dos antigos que já haviam alcançado esta natureza perfeita. A teoria neoplatônica - e maneirista - da imitação de uma beleza ideal cuja origem não é a natureza, é Deus, será defendida sobretudo por Lomazzo e esclarece a função da imagem artística para a Contra-Reforma (cf. Lee, 1998: 21-37).

Obedecendo ao preceito da imitação, manifesta o pintor acadêmico, pela inventione, sua cultura e seu engenho. A inventioneinventio retôrica - corresponde à escolha do tema e à organização 
Mello, Celina Maria Moreira de. O modelo literário humanista e a legitimação do pintor...

geral da composição, que pressupõe uma cultura dita "literária", uma vez que os temas valorizados, chamados de "históricos", são narrativos. Podem ser temas antigos ou modernos, sagrados ou profanos, retirados da tradição da História ou da Poesia. Exigem que o pintor acadêmico conheça as Sagradas Escrituras e os textos da Antigüidade.

$\dot{E}$ inserido neste sistema de valores que devemos compreender um debate acadêmico voltado para os méritos diferenciados do pintor desenhista e do pintor colorista. O debate que opôs em sua origem a Escola de Florença, dos desenhistas, à Escola de Veneza, dos coloristas, disserta sobre qual o melhor meio técnico - o traço ou a cor - para conferir harmoniosamente unidade a um quadro. Para a Real Academia, de acordo com a tradição acadêmica florentina, a unidade de um quadro resulta da correta execução técnica do plano ou desígnio.

A questão em jogo vai além das simples diferenças quanto ao conhecimento técnico exigido de um acadêmico, em seu reconhecimento como um grande pintor, pois desenho não é apenas a palavra que convoca o sistema de formalização do espaço, na pintura, ou seja, o conjunto de conhecimentos de um modo de representação do espaço, que foi chamado de perspectiva e que foi dominante, no campo da pintura, até o início do século XIX. Em todos os discursos e tratados sobre o Belo na Pintura, vinculados ao espaçohistórico clássico, encontramos a palavra desenho - dessin, grafada como dessein - desígnio, intenção, o que gera uma forte ambigüidade semântica e aponta para uma valorização do traço por seu caráter de representação da Idéia. A palavra francesa dessin, ao traduzir o italiano disegno, introduz a conotação da intencionalidade do fazer do pintor.

O conceito de dessein corresponde assim, por um lado, a uma dimensão idealista e racionalista, da arte e, por outro lado, ao deslocamento de Roma, para Paris, do centro produtor e irradiador de parâmetros estéticos (cf. Heinich, 1993: 66-71). O desenho/desíg- 
nio é, pois, a expressão e o fundamento de um sistema de valores pictóricos, tributário de um sistema filosófico platônico-aristotélico e cristão, revisto à luz da Retórica clássica. Assim, em suas Observações sobre a pintura, Poussin afirmará que: "A Pintura nada mais é do que uma idéia das coisas incorpóreas e, se mostra os corpos, ela representa apenas a ordem e o modo da espécie das coisas". (apud Hautecoeur, 1963: 15).

Considerando-se o papel do campo das Letras, na constituição e no fortalecimento desta nova identidade social do pictórico, o dessin, de acordo com as regras da Retórica clássica e conforme explicita Annie Becq, encontra-se ligado à escolha do tema ou inventio, assim como a sua concepção global e harmoniosa ou dispositio. Sua expressão é vista como análoga às figuras de pensamento ou elocutio: "As figuras de pensamento se opõem às figuras de palavras, na medida em que elas subsistem, quaisquer que sejam as palavras que sejam usadas." (Becq, 1994: 67).

As regras da arte da composição devem ser obedecidas, tanto pelo escritor quanto pelo pintor. Assim, mais do que um conhecimento da geometria e o domínio da técnica do traço, será valorizado o trabalho intelectual investido pelo pintor criador. A composição, no caso do pintor, exige o respeito às leis da proporção, representa o trabalho intelectual presente na obra e reflete sua concepção, considerada, então, superior a sua execução. O domínio de uma "retórica pictórica" serve, portanto, de apoio para a construção deste personagem de pintor criador que se legitima mirando-se no poeta, em uma perspectiva neoplatônica.

A oposição entre arte da composição e arte da execução apresenta a mesma clivagem que separa a pintura vista como arte liberal e nobre, da pintura arte mecânica e vil. Distingue-se, aqui, o pintor intelectual, o desenhista, do pintor artesão, o colorista. Essa clivagem não apenas continua a redistribuir valores sociais e econômicos, mas impõe determinados padrões estéticos no campo da pintura. 
Mello, Celina Maria Moreira de. O modelo literário humanista e a legitimação do pintor...

\section{Modelos literários e gêneros pictóricos}

Como resultado dessa intensa atividade acadêmica de regulação e controle institucional do campo do pictórico, consolida-se uma rigida hierarquia de gêneros, que segue os cânones impostos pelas Poéticas clássicas, na esteira da tradição aristotélica. O gênero do quadro, que responde pelo prestígio do pintor e também por seu valor de troca, será definido por seu tema. Os quadros de maior valor são os de "história", seguidos dos retratos, das cenas de gênero, das paisagens e, por último, as naturezas mortas (cf. Heinich, 1993: 77-90).

Os grandes pintores são os pintores de história, quer sagrada, quer profana, gênero que se define pela referência a um texto religioso, mitológico ou histórico. Fëlibien, entre outros, afirma que, para alcançar a "alta perfeição da arte", um pintor deve retirar seus temas da "história e da fábula", "representar as grandes ações como os historiadores" e também "representar os temas agradáveis como os poetas". Mas, acima de tudo, o grande pintor será aquele que, em suas "composições alegóricas", for capaz de "cobrir com o véu da fábula as virtudes dos grandes homens, e os mais altos mistérios" (apud Heinich, 1993: 259).

Portanto, na categoria de pintura de história, em primeiro lugar vem a alegoria, ainda chamada de maravilhoso, pela Retórica. É preciso registrar que a alegoria havia, pouco a pouco, perdido seu sentido místico medieval - "manifestação das relações secretas que existem entre as coisas" (Hautecoeur, 1963: 11) - e passara a personificar qualidades morais. Deste modo, as divindades pagãs da mitologia greco-romana, na pintura de história acadêmica, encarnam valores morais, religiosos e politicos.

Dominam a categoria de alegorias mitológicas os quadros que representam o rei Luís XIV, os quais recorrem à figura de Apolo, o deus-sol. Os quadros multiplicam-se e o motivo é recorrente, para poetas e pintores, assim como nas encomendas de ministros e no- 
bres, almejando todos homenagear o rei em suas obras e na decoração de seus palácios. Vemos, então, determinados exageros, como na decoração do palácio das Tuilerias, em que "o heliótropo (girassol) simboliza o cortesão que, como esta flor, volta-se para o sol, ou seja, para Luís XIV, cujo emblema era uma cabeça de Apolo, coroada de raios de sol." (Hautecoeur, 1963: 13).

Depois das alegorias, vêm os quadros representando ações heróicas, sendo que o quadro que representa deuses é superior àquele que representa homens. Reis e generais valorizam um quadro mais do que a presença de lenhadores, uma vez que a hierarquia de gêneros reproduz e fortalece a estratificação social. Encontramos a mesma valorização e distribuição de personagens de teatro que fazem de reis e príncipes, filhos de reis e filhos de príncipes, heróis de tragédias e de burgueses e serviçais, personagens cômicas.

Fiel à dimensão humanista da representação, a pintura acadêmica vê no homem o centro das telas. Assim, a paisagem sem a presença humana não é apreciada e a pintura de gênero e as naturezas mortas ocupam o lugar mais baixo nesta escala de valores. Observe-se que as mulheres não podiam ser pintores de história, apenas de naturezas mortas, gênero entre todos inferior.

Eis a razão pela qual, para a Real Academia, o pintor de história, bem como seu homólogo o poeta, mais precisamente o autor de tragédias, deverá escolher nas narrativas sublimes um tema dramático para suas obras e respeitar as regras das três unidades, na tragédia - de tempo, lugar e ação. Estas são, para o pintor, de acordo com Testelin, aquilo que acontece em um só tempo, que a vista pode descobrir de imediato com um único olhar e aquilo que pode ser representado em um único quadro (Hautecoeur, 1963: 16).

A supremacia atribuída à pintura de história explica-se, por um lado, pela erudição exigida do pintor, que na escolha do tema comprovava conhecer os textos da tradição letrada, tais como a Bíblia Sagrada, as Epopéias ou as Tragédias clássicas, ou ainda as 
Mello, Celina Maria Moreira de. O modelo literário humanista e a legitimação do pintor...

Teogonias. Por outro lado, trata-se de um gênero que, na prática, compreende o conhecimento e o domínio das técnicas requeridas pelos outros gêneros da pintura: em um quadro de história poderão estar presentes todos os gêneros pictóricos: o retrato, as paisagens, as cenas de gênero e até mesmo naturezas mortas. E, finalmente, a pintura de história possibilita ao pintor exibir o domínio de duas técnicas presentes apenas em quadros que representam cenas da História antiga, da Mitologia ou com valor alegórico: a representação do corpo humano nu e a reprodução dos panejamentos em túnicas, cortinados, tendas e tapetes (cf. Heinich, 1993: 81).

A erudição exigida, para construir alegorias com referências à História sagrada ou profana, ou ainda mitológicas, e as dificuldades técnicas de execução destes temas vêm justificar o prestigio e os privilégios dos pintores de História. Apenas esses podiam ocupar determinados cargos, como os de tesoureiro, reitor, chanceler, diretor, ou gozar de certas vantagens, como o título e a função de professor, pensões pagas pelo rei e alojamento no Louvre (cf. Heinich, 1993: 83).

A Literatura, que no espaço-histórico clássico compreende também a Filosofia e a História, empresta, pois, seus temas à pintura, uma vez que a leitura dos textos da tradição, a escolha dos temas e a fidelidade com que estes são tratados serão responsáveis pelo reconhecimento de um pintor por seus pares - os acadêmicos - e por seu prestígio junto a um potencial público comprador, o rei, os nobres, os ricos burgueses.

A figura do pintor de história, filósofo e erudito, domina o funcionamento da Academia e constitui a maioria em seus quadros. E a pintura de história será o gênero de maior prestígio, até a ruptura com os padrões acadêmicos, no século XIX. Entretanto, muito rapidamente, para a segunda geração de acadêmicos e para os amadores, o retrato aparecerá como o gênero mais propicio a suscitar interesse e apaixonados debates. Não se trata, de modo algum, para o pintor, de realizar retratos "realistas", mas de confe- 
rir ao modelo uma estatura simbólica ou histórica. Essa dimensão estará presente em retratos do rei ou dos nobres da corte que os representam como figuras mitológicas ou históricas da Antigüidade, na mise-en-abyme barroca do retrato no retrato, assim como em representações do próprio artista - o auto-retrato.

Para além da importância do modelo ou da transformação das técnicas pictóricas é conferido um grande destaque à discussão fisiognomônica da relação das formas do rosto e do gesto das mãos com o caráter do modelo. Tema que é testemunha do processo de recíproca legitimação de pintores e letrados e se torna "uma moda nos meios literários" (Brême, 1997). Assim, no final do século XVII, o gênero do "retrato", que constituía a formalização de um ideal de grupo que se quer universal, foi substituído pelo "caráter" visto em sua singularidade e complexidade psicológica:

Mas se em meados do século XVII, bastava que fossem descritas as belezas ou os defeitos físicos, as virtudes ou as fraquezas morais, e que fossem estabelecidas tipologias, no final do reinado de Luis XIV, desenvolveu-se um interesse cada vez maior dos intelectuais pela economia dos mecanismos psicológicos e as anomalias comportamentais. (Brême, 1997: 11)

Pintor e letrados, irmanados por um fazer poético, encontramse em uma atividade de caráter filosófico que interroga as relações entre identidade e aparência. Contudo, o "retrato", gênero pictórico, e o "caráter", gênero literário, continuavam a ser considerados menores à luz dos cânones poéticos humanistas que valorizavam, acima de tudo, a pintura de história, a epopéia e a tragédia. E além disto, diante do valor narrativo de um quadro ou um texto literário, a descrição parece constituir uma presença acessória. Mas a voga do "retrato" e do "caráter" marcam ambos uma preferência do público comprador de quadros e do leitor de obras literárias, que vai perdendo suas referências eruditas e que contribuirá, a seguir, para a crescente aceitação, nos meios acadêmicos, da pintura de gênero e do romance psicológico. 


\section{O amador}

A busca de legitimação que observamos no progressivo espelhamento entre a personagem social do pintor acadêmico e a do homem de Letras toma corpo, integrada a um conjunto de textos voltados para uma reflexão filosófica sobre a arte, que se constituirá, no século XVIII, como campo específico, aquele da Estética ou reflexão de caráter normativo sobre a beleza e os sentimentos que desperta.

Os pintores Acadêmicos distribuíam-se, estatutariamente, em três categorias, o que obedece, por um lado, à hierarquia dos gêneros e, por outro lado, à valorização social a que aspiram pintores (e escultores). As duas primeiras categorias compreendem os pintores, conforme o gênero que praticam. A terceira categoria será a do amador: "[...] alguns particulares que sem serem pintores, escultores ou gravadores têm, contudo, gosto pelas belas-artes, e eles são chamados conselheiros-amadores." (Heinich, 1993: 83).

Esta terceira categoria, na prática, abre as portas da Academia para nobres ou ricos burgueses que não são pintores nem escultores "profissionais" e que vão possibilitar uma efetiva integração social dos artistas, nos meios cortesãos ou nos salōes parisienses, além de constituírem um potencial público para as obras, ampliando assim o mercado comprador de artes plásticas. As conferências assumem, destarte, uma capital importância, atendendo ao duplo objetivo de "educar" este potencial público comprador e fortalecer junto a ele a autoridade do pintor acadêmico, construindo e consolidando uma relação de superioridade do artista em relação ao comprador. $^{12}$

Uma esfera de atividades integra a categoria de conselheirosamadores e a categoria dos artistas, e é especificamente aquela que

\footnotetext{
12 A introdução da técnica da pintura a óleo e o uso dos suportes de madeira e tela aumentam a capacidade produtora do artista, embora para alguns a pintura de cavalete seja inferior aos afrescos, o que acarreta em estratégias para aumentar o público comprador.
} 
exige o conhecimento do letrado, uma erudição humanista, uma reflexão sobre o Belo e o Gosto. Esta se desdobra nas atividades de ensino, nas conferências e na escrita de textos sobre as relações entre a pintura, a natureza e a verdade. Artistas e amadores encontram-se nessa escrita, aparentemente compartilhada, de textos críticos, embora, na realidade, os textos escritos pelos amadores sejam em número bem maior e mais expressivos do que aqueles escritos pelos pintores. Representando a categoria dos pintores, Nicolas Poussin, na esteira dos trabalhos de Leon Battista Alberti, Leonardo da Vinci e Albrecht Dürer começa a escrever um Traité d'Art, de que foram conservados apenas alguns fragmentos. E os documentos mais importantes de que dispomos para conhecer sua concepção da pintura são os resumos de suas conferências e sua correspondência. Na categoria dos amadores destacam-se, no século XVII, as figuras de André Félibien, autor da monumental obra Entretiens sur les vies et les ouvrages des plus excellents peintres anciens et modernes e Roger de Piles, com seu Cours de Peinture par principes. $\mathbf{E}$ a essa categoria que devemos, fundamentalmente, o desenvolvimento e o registro de uma reflexão estética "acadêmica" que fez, definitivamente, do pintor acadêmico um artista criador. A tradição humanista de escritos de autoria do pintor erudito, com uma sólida formação filosófica e literária, será retomada, bem mais tarde, no século XIX, por Delacroix.

\section{Conclusão}

No espaço-histórico clássico, há uma mudança de valores em jogo, vinculados a uma redistribuição das atividades do pintor, que opera desde o Renascimento. Entretanto, o novo "sistema de distribuição humanista" ainda conviverá muito tempo com o antigo "sistema de distribuição medieval". O Humanismo renascentista almejou a que se pense a atividade do artista não mais enquanto arte 
Mello, Celina Maria Moreira de. O modelo literário humanista e a legitimação do pintor...

manual, puramente mecânica, mas enquanto arte liberal, ou seja, de especulação intelectual, em um paralelo com o trabalho de gramáticos, retóricos, lógicos, aritméticos. Rompe-se, para um dado grupo social, um sistema de valores medieval e este grupo fará do diálogo com o campo das Belas-letras uma estratégia de legitimação, que pode ser observada na constituição do campo das Belasartes, na elaboração de uma teoria da pintura e no estabelecimento e consolidação de uma poética dos gêneros pictóricos. A categoria do acadêmico amador abre possibilidades para novas práticas sociais e discursivas: as de uma reflexão filosófica que interroga o Belo e o Gosto e a da crítica de arte.

RÉSUMÉ: La France du XVII siècle confère à la Littérature un statut supérieur à celui de la Peinture. Nous avons voulu saisir ici le moment fondateur de nouveaux rapports de sens qui s'établissent entre la Littérature et la Peinture dans un découpage que nous dénommerons espace-historique classique: la tradition littéraire humaniste va servir de modèle au processus de valorisation du pictorique. L'espace-historique envisagé est celui de la fondation de l'Académie Royale de Peinture et de Sculpture, en France. Celle-ci se propose, en effet, de procurer à ses membres un statut intellectuel et social analogue à celui dont jouissaient les écrivains de la toute récente Académie Française des Lettres. Prenant ses distances vis-à-vis de l'artisan, le peintre se rapproche ainsi du poète et prend désormais modèle sur le lettré humaniste pour composer le nouveau personnage de l'artiste.

MOTS-CLÉ: Littérature française; peinture; genre.

\section{BIBLIOGRAFIA}

$\mathrm{BECg}, \mathrm{A}$. (1994) Genèse de l'esthétique française moderne; de la raison classique à l'imagination créatrice. Paris: Albin Michel. 
BRÉmE, D. (1997) Fards et codes du grand-siècle. In: Visages du grand siècle; le portrait français sous le règne de Luis XIV. Beaux Arts Magazine. Hors série. juin 1997.

Gombrich, E. H. (1993) A história da arte. Rio de Janeiro: LTC.

Hautecoeur, L. (1963) Littérature et peinture en France du XVII $a$ au XXe. Paris: Armand Colin.

Heinich, N. (1993) Du peintre à l'artiste; artisans et académiciens à l'âge classique. Paris: Minuit.

LEE, R. W. (1998) Ut pictura poesis; humanisme et théorie de la peinture: $\mathrm{XV}^{\mathrm{e}}$ - XVIII ${ }^{\mathrm{e}}$ siècles. Paris: Macula.

Lichtenstein, J. (1997) La peinture. Paris: Larousse-Bordas.

Mainguenau, D. (1993) Le contexte de l'oeuvre littéraire. Paris: Dunod.

Maingueneau, D. \& Cossutta, F. (1995) L'analyse des discours constituants. Langages. Paris: n. 117, p. 112-25. 